\title{
Rethinking Intellectual Property Rights in the Cognitive and Digital Age of Capitalism:
}

\section{An Autonomist Marxist Reading ${ }^{i}$}

\begin{abstract}
The transition from industrial capitalism to cognitive capitalism and the rise of the digital revolution have brought the subject of intellectual property rights to the forefront as a controversial issue. This paper holds that the theoretical apparatus and concepts belonging to the industrial phase of capitalism largely fall short with respect to the repercussions that intellectual property rights regime yields. Embracing the methodological precept that social theory must be moulded in order to address the contours of contemporary social reality, this paper engages in an autonomist Marxist update on the concept of intellectual property rights. It ultimately challenges the "intellectual property rights are a socio-economic need" thesis and speculatively argues that the current system of intellectual property rights, directed politically towards the enclosure of commons, constitutes a structural contradiction by i) forming a basis for a social crisis in terms of the established relations of production, and ii) curtailing a part of the socioeconomic opportunities for innovation, profit-making, and growth.
\end{abstract}

Keywords: intellectual property rights, cognitive capitalism, immaterial production, digital revolution, the common, autonomist Marxism. 


\section{Introduction}

In industrial capitalism, the juridical and institutional arrangements that regulate the content and implementation of property rights in general and intellectual property rights in particular were not always at the forefront as a subject of debate. Especially in the latter case, the overall volume of "intellectual" products such as knowledge(s), designs, ideas, codes, images was quite limited (largely R\&D specific), and their trade under monopolistic conditions was structured and secured by the mechanisms of patents, trademarks/branding, and copyright. The central function of these mechanisms was to facilitate the transformation of these immaterial products into forms of scarce commodities on the market. In this way, the owners of intellectual property rights could possess a sort of monopoly before the law and thus enjoy the profits it brought. Enclosure, in other words, was largely an unproblematic presupposition of capitalist relations.

With the transformation of industrial capitalism into cognitive capitalism (Boutang, 2011; Corsani, Dieuaide, Boutang et al., 2001; Dieuaide P, Paulré B and Vercellone, 2003; Fumagalli, 2011; Lucarelli and Vercellone, 2013; Negri, 2008; Paulré, 2000; Vercellone, 2007), nevertheless, something has happened and, as a consequence, the subject of intellectual property rights has come to the forefront as a distinctive issue on both public and academic platforms. This something, we will argue, the tendency towards the organisation of (immaterial) production within and through the common and the rise of the digital revolution. In cognitive capitalism, specifically, the value and wealth have come to rest on immaterial production which is increasingly conducted within and through the common. This development is accompanied by the massive diffusion of the results of immaterial production (e.g. knowledge, idea, code, images) largely free by means of new information and communication technologies. These developments have created a "threat" to well-established relations of capitalism. One of the apparatuses to intercept the free circulation of immaterial products and the emerging marriage between workers and means of production has been directed towards the enclosure of common through the aggressive enforcement of intellectual property rights. 
This political reading stimulates me to re-address a fundamental question: is the extension and implementation of intellectual property rights a precondition for economic health? For those who draw on neoclassic economic theory, the answer tends towards "yes" -even though ambivalence marks the literature. In this very journal and beyond, for example, the enclosure via intellectual property rights has largely been viewed as an apparatus that must be strengthened to increase companies' 'financial performance' (Bollen, Vergauwen and Schnieders, 2005; Suh and Oh, 2015; Willoughby; 2013), to sustain 'innovation' (Horbulyk, 1993; Hu and Hung; 2014; Pérez, Kunch, Durst et al., 2018; Sweet and Maggio, 2015), and to facilitate economic growth (Gould and Gruben, 1996; Park and Ginarte, 2007). In turn, Archibugi and Filippetti (2018), Baker, Jayadev and Stiglitz (2017), Boldrin and Levine (2002, 2010), Lerner (2009), Stiglitz (2014), developed alternative arguments, challenging these general assumptions to a certain extent.

In this paper, I will contribute to the second position by problematizing the "intellectual property rights are a socio-economic need" thesis by engaging in a critical update on the concept through autonomist Marxist theory. In the second and third sections, I will focus on the current state of socio-economic affairs and offer a 'political reading' (Cleaver, 2000) of intellectual property rights, respectively. I will bring forward that the aggressive enforcement of intellectual property rights pertains to, first and foremost, the re-separation of wage-workers from the ownership of the emerging means of production. In the fourth section, I will discuss the structural contradiction manifested by the capital's desire to enclose via intellectual property rights. In particular, I will speculatively argue that the current regime of intellectual property rights i) prepares a basis for a social crisis in terms of established relations of production and, at the same time, ii) curtails a part of socio-economic opportunities for innovation, profit-making, and growth. A brief conclusion will ensue.

\section{Cognitive Capitalism and The Becoming of Production Common}


Capitalism is an unstable, destructive, and crisis-prone mode of production. Thrift notes that 'we live in a world that exists on the economic edge, close to an abyss but never quite falling into it ... It [capitalism] is like a battery that continues to accumulate energy without pause' (2011: vi). Capitalism survives; and it survives precisely by transforming itself into a new modality. Tronti (1979) formalised one of the most important methodological lessons for the study of the transformation of capitalism, which is acknowledged within autonomist Marxist theory as a sort of 'Copernican revolution' (Toscano, 2009: 114). He puts that 'we too have worked with a concept that puts capitalist development first, and workers second. This is a mistake... At the level of socially developed capital, capitalist development becomes subordinated to working class struggle; it follows behind them, and they set the pace to which the political mechanisms of capital's own reproduction must be turned' (Tronti, 1979: 1) ii. That is, working class is always anterior in the 'reactive history' (Hardt and Negri, 2000: 268) of capitalism; it sets the terms and nature of transformation. Embracing this lesson, MATISSE scholars and other autonomist Marxist theorists have periodised capitalism by placing emphasis on one of the central dimensions concerning the reactive history of capital-labour relation, namely the control of 'the intellectual powers of production' (Marx, 1990) iii.

Capitalism is older than industrial capitalism. The first period in the trajectory of capitalism in the Braudelian longue durée was discerned as mercantilist capitalism, developing between the beginning of the sixteenth century and the end of the eighteenth century. The model of production in this period was based on the system of putting-out model or concentrated manufacture with its main capitalist persona, mercantile entrepreneur. While the latter was enjoying the fruits of production by appropriating surplus-labour, the production itself was largely organised and executed by independent artisans, craftsmen, artists working in cooperation and collaboration. In this period, Vercellone notes, 'capital subsumes a labour process ... which pre-exists it and in which the co-operation of workers does not require mechanisms of capitalist direction of production' (2007: 20). From technical point of view, in other words, the production process was 
autonomous in relation to capital. In this regard, the central "concern" from the perspective of capital was that even though workers depended strictly on the figure of mercantile entrepreneur in monetary terms, they were in fact powerful actors in political terms, for they were controlling the intellectual powers of production. Accordingly, the workers could always resist mercantile entrepreneur and claim control over the organisation, methods and intensity of the production process. Therefore, in this period, Marx states, 'capital is constantly compelled to wrestle with the insubordination of the workmen' (1990: 489).

It was not a historical coincidence that mercantilist capitalism dissolved and industrial capitalism began with the arrival of cutting-edge (for that period) technological innovation and progress. The industrial-technological revolution conditioned the rise of industrial capitalism, the second period in the longue durée. The industrial capitalism eventually found its historical fulfilment in the Fordist system of accumulation, whose driving force was Manchester-style big factories with heavy machinery and assembly lines. The specialisation was primarily in the mass-production of durable and standardised goods. The organisation of labour was typically administered through scientific methods (e.g. Taylorist production methods), involving the establishment of prescribed simple-tasks, performed in pre-determined time-slots and measured by a chronometer.

What capital achieved with scientific methods and machinery is diverse. What interests us here, nonetheless, is the results of the integration of labour into intricate processes of machinery from the perspective of working class. In industrial capitalism, Marx argues, 'the production process ceases to be a labour process in the sense of a process dominated by labour as its governing unity. Labour appears, rather, merely as conscious organ ... subsumed under the total process of the machinery itself' (1993: 693). Technology and machinery terminated the hegemony of workers' "living" knowledge over "dead" knowledge of capital by separating the workers from cognitive elements of work. They facilitated capital to decompose the autonomous worker and establish 
control over the intellectual powers of production. The worker became an 'ox than any other type' (Taylor, 1911: 59).

How can we think of the dynamics of transition from industrial capitalism to cognitive capitalism? The main argument of autonomist Marxist theory is that it was precisely the accumulated social struggles of workers in the 1960s and 70s against the deepening of Fordist mode of working and living that brought about the structural crisis of industrial capitalism (Castellano, Cavallina, Cortiana et al., 1996). The mass insurgency, first, led to the 'development of the institutions of the welfare state, [above all] mass education was established' (Vercellone, 2007: 25). It, second, led to the extension of wage and hence created a new margin for converting a part of surplus-labour into free time. The free time spent on education, research, art, communication, public interaction and all other activities of human development 'permitted wage-labourers to accumulate a technological, theoretical, and practical knowledge adequate to the level attained by the capitalist development of the social and technical division of labour' (Vercellone, 2007: 27). This state of affairs was termed 'mass intellectuality' by Virno (1996) and 'diffuse intellectuality' by Vercellone (2013) which denotes, the intellect that is diffused across the whole society. The workers of mass intellectuality consequently began to demand more creative, flexible, communicative, innovative, or in a word, more fulfilling forms of labour which will correspond to their cognitive capacities.

Once again, workers invented and 'dictated the terms and nature of [capitalism's] transformation' (Hardt and Negri, 2000: 268). Indeed, capital had to address the demands of workers because capital produces nothing without labour, which is the sole element of value creation (Marx, 1990). Capital responded to the demands by mutating itself into a new form, a new 'system of capital accumulation' (Dieuaide, Paulré, Vercellone, 2003), which was based on the mobilisation and absorption of the creative, innovative, affective, relational, and communicational capacities of workers. In contemporary capitalism, the principle source of value and wealth does not lie much in manual labour (e.g. physical-energy, dedicated to the accomplishment of prescribed tasks) but 
increasingly in the ensemble of mental and affective capacities of workers which are set in motion in production processes. This new system of accumulation entered into the autonomist Marxist literature as cognitive capitalism iv. At this point, we need to elucidate that what is cognitive in cognitive capitalism is not capitalism but the labour upon which the extraction of surplus-value rests. One of the most prominent figures of autonomist Marxism, Vercellone, defines the concept as follows:

'Capitalism' refers to the persistence, within the process of change, of certain fundamental invariants of the capitalist system, such as the driving role of profit and the centrality of the wage-relation, or more precisely of the various forms of dependent labour upon which the extraction of surplus-value rests. 'Cognitive' draws attention to the new character of the labour, value-sources and property forms on which the accumulation of capital is now based, as well as to the contradictions thereby engendered. (2013: 418)

The rise of cognitive capitalism, a new system of accumulation which succeeds mercantilist and industrial capitalisms, is reflected in the tendency that immaterial products (e.g. knowledge, codes, ideas, information, symbols, images, logos, designs) or immaterial dimensions of products (i.e. their symbolic, aesthetic, and social value) have come to preponderate over material products or the material dimensions of products in the process of capitalist valorisation (Lazzarato, 1996; Hardt and Negri, 2009). This does not to convey that the production of material commodities (e.g. computers, cars, furniture) is in the process of gradual disappearance. Instead, the argument is that the value of material commodities too increasingly rests on intangible factors. In their report to the The French Ministry of Treasury, Lévy and Jouyet put that 'in recent years, a new constituent has emerged as a key driver in the economic growth: immaterial... Today, the real wealth is not concrete, it is abstract. It is not material, it is immaterial' (2006: 1, my translation). For Morini and Fumagalli, the creation of wealth and value is increasingly based on immaterial production 
hence subordinated to the use of 'intangible raw materials' (2010: 235). For Boutang, the capture of gains from immaterial elements, constitutes 'the central issue for accumulation, and it plays a determining role in generating profits' (2011: 57). Vercellone, along the same line, argues that 'the component of capital intangible, which is essentially embodied in human beings, now makes up a larger part of the overall capital-stock than material capital, becoming the crucial growth factor' (2013: 434).

One of the key characteristics of immaterial labour is that it intrinsically exceeds the bounds set in relation to capital. Excedence seems to me an underdeveloped notion -even in the literature mentioned above. By excedence, one might envision two ideas. First, with the great mutation from industrial capitalism to cognitive capitalism, 'we pass from the static management of resources to the dynamic management of knowledges' (Vercellone, 2007: 33). That is to say, 'the knowledge mobilised by living labour is now hegemonic with regard to the knowledge embodied in fixed capital' (Vercellone, 2013: 433). Boutang underlines that 'the essential point is no longer the expenditure of human labour-power, but that of invention-power: the living know-how that cannot be reduced to machines' (2011: 32). Therefore, on the one side, we affirm that today's economic production is directed towards absorbing the creative, innovative, affective, relational, and communicational capacities of living labour. On the other side, in immaterial production, labour is not crystallised in a material commodity that can be divorced from its producer. A car, for example, which is produced with material labour is immediately divorced from its producer. However, a research article, a code, an analysis, and alike cannot be divorced from the producer inasmuch as these products intrinsically reside within the mind and body of those who produced them in the first place. Therefore, immaterial labour increasingly exceeds; it potentially overflows the subsumption mechanisms set by today's economic production.

Secondly, in industrial capitalism, which found its fulfilment in Taylorist production processes, workers' innovative, creative, technical capacities were rigorously confined to a particular site, 
that is, the site of material production. Consider, for instance, an assembly line worker producing in a cable factory. The whole ensemble of technological and mechanical knowledge s/he has accumulated through her/his lifetime was rarely put into work, and more significantly, those put into work were almost exclusively site specific. However, the production of immaterial products or immaterial elements of material products immediately mobilises producers to actualise and ameliorate their intellectual, communicational, affective, and social capacities. Furthermore, the results of immaterial labour, not confined by the corporate walls, exceed work and spill over different spheres of life (as economists call externalities), and they begin to produce the common forms of wealth. This is the point from where one might begin to envision the linkage between the excedence of immaterial labour and the accumulation of immaterial products in the common.

De Angelis (2004), Hardt and Negri (2004, 2009), Negri (2008), Fuchs (2010), Hardt (2011), and Vercellone (2017) have theorised immaterial production with its connection to the concept of common. What is meant by the common? Typically, the common denotes the wealth of nature (e.g. earth, water, air, elements, animal life) to be shared by all humanity. In other words, the common refers to the natural world, harbouring the natural resources, outside of society. By a fair extension, the common also denotes 'those results of social production that are necessary for social interaction and further production' (Hardt and Negri, 2009: viii, emphasis added). The concept of common thus permeates equally all spheres of life, blurring the division between nature and culture, referring not only to the fruits of nature shared by human beings but also, and above all, to the artificial common(s): the creative, social, knowledge common(s); for example, the languages we construct, the knowledge we create, the social practices we enact.

According to this second formulation, the common makes an appearance both at the beginning (as a presupposition) and at the end (as an outcome) of immaterial production. To put it more precisely, the common consists of both the results as well as the means of immaterial production. In terms of being the presupposition, it might appear convincingly in mind that immaterial labour 
performs, and it can actually perform only on the terrain of common. Indeed, no one produces all alone but only within and through the spectres of the others' past and present existence. Consider, for example, the production of immaterial products such as ideas, knowledge, solutions, images, codes, language, and so forth. These products cannot really be produced by such a persona of "genius" in an ivory tower, that is, by a human being who is entirely isolated from the accumulated common intellect. Marx elegantly notes that knowledge and such products are 'universal labour', that is, 'brought about partly by the cooperation of men now living, but partly also by building on earlier work' (1992: 199). As Hardt and Negri maintain, 'our common knowledge is the foundation of all new production of knowledge; linguistic community is the basis of all linguistic innovation; ... and our common social image bank makes possible the creation of new images' (2004: 148). The workers then must have an open-direct access to the common intellect in order to produce. This open-direct access to the common is essential for one's creativity, productivity, and more importantly for the realisation of one's potentiality.

The outcome of immaterial production, on the other side, exceeds and accrues to the common that then becomes a condition for the expanded production. The results of immaterial production are not identical to material products, for they immediately tend towards being common through their circulation in social, cultural, and digital networks. Gorz argues that when knowledge is produced and diffused, 'it no longer has proprietors' (1997: 18, my translation). From the perspective of economics, Boutang argues (2013) that today scarcity is no longer fatal. What we witness is that the 'digital world restores abundance that had been destroyed partly or fully by industrial organisation of scarcity of commons' (Boutang, 2013: 86). In other words, since the outcome of immaterial production can be coded in the digital media, reproduced, and delivered virtually at zero marginal cost, we may speak of the inversion of scarcity of commons in terms of immaterial products. Considering the technical developments, in particular the peer-to-peer protocols, Boutang underscores how the digital revolution has challenged (with respect to immaterial products) the statue of 'a) reproduction; b) monopoly of circulation; c) authority that 
tackles with monopoly in interpretation; d) and finally authorship' (2013: 86). The latter aspect of the commonality as well as how capital counter-acts will be discussed in the final part of this chapter.

So, what we have here is a sort of virtuous cycle which is typical of immaterial production process. Immaterial labour force, through working on the accumulated common forms of wealth, create new commons which, in turn, becomes the base (i.e. raw materials) for expanded production. Fuchs (2010) upholds that all humans benefit from the commons: the present generation works on the commons produced in the past and then hands over enriched commons to the future generation. From what we have noted until now, we can discern another aspect of immaterial production. Let me to consider, for instance, the production of scientific knowledge. The potential outcome in our case might be a journal paper, monograph, conference speech, series of lectures, accruing to the general intellect and, at the same time, contributing to the ground basis for the production of further scientific knowledge. We have already pointed this out. In addition, the production of scientific knowledge necessitates, by its nature, engagement in communication, cooperation, collaboration, affective relation etc. between researchers, students, supervisors, editors, reviewers, and fellow academicians. Marx writes that 'communal labour ... simply involves the direct cooperation of individuals' (1992: 199). No scientific knowledge, no idea, no computer code, no natural language, no artificial language, no authorship etc. can be produced without this sort of engagement. From this point of view, the common appears at the centre as well. That is to say, the immaterial production is increasingly conducted in the common. In this respect, Negri puts that:

We assume not only that value is constructed within social production (which is obvious), but also that social production today presents itself in a manner which increasingly has the quality of the common, in other words as a multiplicity of increasingly cooperative activities within the process of production. (2008: 183) 
To sum up, the general outlines of the technical composition of immaterial labour indicate the growing autonomy of the labour process. First, the workers of diffuse intellectuality tend to get direct access to the common where the raw materials of production are located. They work on it in cooperation and collaboration and produce a new product that tends towards to common, which facilitate tomorrow's production. In addition, Hardt and Negri recognise that 'labour itself tends to produce the means of interaction, communication, and cooperation for production directly' (2004: 147). Producers, in this context, are virtually in no need of a figure from "outside" (e.g. leaders, capital owners, board of directors, shareholders, state representatives) that would administer the design, surveillance, and control of labour process. Production tendentially reveals itself as a sort of shared; a common process. The essential aspects of economic production no longer have to be made available by an "outsider" because these aspects increasingly flourish internally within the networks of production (i.e. by-product). The increasing power and growing autonomy of workers, based on the control of intellectual powers of production, had created a threat to existing capitalist production relations which was, in turn, counter-acted by various political mechanisms enforced by the forces of "outside" v. One of the key mechanisms has been oriented towards enclosing the common.

\section{Enclosure of the Common: Revisiting 'So-Called Primitive Accumulation'}

One of the most enlightening ways to approach the enclosure of the common will be revisiting Part Eight of Capital volume I, So-Called Primitive Accumulation (1990: 873-940), where Marx often uses the terms of primitive accumulation and enclosure interchangeably. This is rather a controversial part in Capital which has predominantly been read through three different lenses within the Marxist literature. After discussing the first conventional interpretation briefly, I will focus on Bonefeld's $(2001,2002)$ reading which separates itself from the former fundamentally. 
I will then articulate my position through De Angelis $(1999,2001,2004)$, contributing to Bonefeld by reading Marx "politically" (see Cleaver, 2000).

The historicist interpretation of primitive accumulation is evident within the works of Lenin (1899), Dobb (1963), and Sweezy (1986). Here, the primitive accumulation is conceptualised as a temporally crystallised process whereby the preconditions of capitalist mode of production (i.e. (i) a section of population divorced from all means of production but their labour power, and (ii) an initial accumulation to be used for emerging industries) have emerged. Here, the primitive accumulation conveys, above all, 'causality, where an historical event is understood to have caused the formation of a distinct mode of social relations which renders the causing event obsolete' (Bonefeld, 2002: 3). Accordingly, the accent is on the transiency of the phenomenon; that is to say, once the process (a history of blood and fire, as Marx says) had been completed, we were no longer in the realm of primitive accumulation. Embracing this perspective, one inquiries into either the transition from feudalism to capitalism by rendering it a question of genealogy or the complex issues of the capital-relation by rendering it a question of economics. Ultimately, both orientations assume a linear model of development, where the primitive accumulation indicates only a one-off epoch that is distinctly separated from capitalism-proper vi.

Bonefeld $(2001,2002)$ and De Angelis's $(1999,2001,2004)$ political and theoretical formulation re-evaluates Marx's primitive accumulation, that is enclosure. Against the conventional one-offin-history thesis, the theorists bring forward an alternative analysis that 'primitive accumulation is necessarily present in mature capitalist systems and, given the conflicting nature of capitalist relations, assumes a continuous character' (De Angelis, 2001: 2, emphasis added). Even though this key argument (i.e. primitive accumulation is a continuous process in capitalist mode of production) is shared by both theorists, they go separate at a certain juncture. 
Bonefeld argues that 'primitive accumulation is Aufhebung in accumulation proper' (2002: 4). The Hegelian term Aufhebung 'connotes the dialectic process in which the negation of a form transforms the negated into a new form, in which it loses its independent existence and at the same time maintains its essence, constituting the substance of the new form' (2002: 4). Translating into our context, the historic form of primitive accumulation is argued to be 'raised to a new level where its original form and independent existence is eliminated (or cancelled) at the same time as its substance or essence (Wesenhaftigkeit) is maintained' (2002: 4 and 6). Bonefeld's perspective thus brings forward two ideas: first, primitive accumulation principally specifies a historical epoch preceding capitalist mode of production; however (this however is everything), second, the essence of primitive accumulation maintains its existence as the indivisible principle of capitalism-proper.

But what is the essence of primitive accumulation that Bonefeld speaks of as a living substance? Marx formulates capital against the definitions given by the vulgar economists. It is not a thing referring to a stock of commodities but, first and foremost, a social relation. For Marx, the capitalrelation embodies a precise 'presupposition', namely 'a complete separation between the workers and the ownership of the conditions for the realization of the labour' (Marx, 1990: 874). In other words, 'which creates the capital-relation can be nothing other than the process which divorces the worker from the ownership of the conditions of his own labour' (Marx, 1990: 874). And, he precisely identifies the process here as primitive accumulation. Primitive accumulation is therefore viewed 'nothing other than the historical process of divorcing the producer from the means of production' (Marx, 1990: 875). The essence (wesenhaftigkeit) of primitive accumulation is thus understood through the term of separation: workers' separation from the means of production.

One may then bring forward (by considering the last quote) that Marx's examination of primitive accumulation defines a question of genealogy ('historical process', Marx says). There is no doubt 
that one can capture akin statements that associate primitive with pre-history or others in which primitive accumulation is identified as the historical presupposition of the capitalism-proper. For example, Marx indeed states that 'primitive accumulation ... is the historical basis ... of specifically capitalist production' (1990: 775). He further states 'a division between [the separation of] ... subjective labour-power from the objective conditions of labour was therefore the real foundation in fact, and the starting-point of capitalist production' (Marx, 1990: 716). Does it then mean that the primitive accumulation was one-off separation process in history? Bonefeld (2001, 2002) provides a closer reading of Marx to answer this question. He refers to the Grundrisse (see. 1993: 459-461) where Marx articulates the distinction between conditions of capital's 'becoming' or arising, and the conditions of capital's 'existence' or being. He argues that the conditions of capital's becoming 'disappear as real capital arises', and the conditions of capital's existence do not appear as 'conditions of its arising, but results of its presence' (Marx, 1993: 459). Marx thusly puts that 'once developed historically, capital itself creates the conditions of its existence (not as conditions for its arising, but as results of its being)' (1993: 459). According to Marx, in simpler terms, 'whatever happened for the first time at the origin of the history of capitalism must logically repeat itself' (Mezzadra, 2011: 305).

Indeed, the continuity of the essence of primitive accumulation is everywhere in Marx's works. In The Process of Accumulation of Capital, Marx argues that 'what at first was merely a starting-point [the separation] is constantly renewed and perpetuated by simple reproduction' in capitalist production (1990: 716). In the Theories of Surplus Value, he argues that 'accumulation of capital ... on the basis of the relationship of capital and wage-labour, reproduces the separation ... on an ever-increasing scale'; therefore, 'accumulation merely presents as a continuous process what in primitive accumulation appears as a distinct historical process' (1971: 315 and 271). In volume III of Capital, he puts that capital proper is 'simply' the separation which is 'raised to a higher power' (1992: 354). Bonefeld $(2001,2002)$ accordingly argues that primitive accumulation is a 
process occurring in present-day capitalism precisely because the accumulation proper indicates a posterior stage that reproduces the very essence of it, that is separation, on a greater scale.

At this point, De Angelis $(1999,2001,2004)$ makes a crucial contribution which informs my position. He does not merely argue that the essence of primitive accumulation (re)presents itself in accumulation proper as a by-product of economic reproduction. He, rather, underlines that it is precisely the processes of ex-novo separation (which characterises the primitive accumulation) that maintain their existence in accumulation proper. He argues that the separation 'must not be seen as the necessary result of its [capital's] dynamic', rather 'as necessary aspiration embedded in its drives and motivation as well as its survival instinct vis-à-vis emerging alternatives to capital' (2004: 69). He elegantly discerns what primitive accumulation in Marx refers to: 'the problematic of the preservation and expansion of the capitalist mode of production any time the producers [and the spaces of life] set themselves up as an obstacle to the reproduction of their separation from the means of production' (De Angelis, 2004: 69). Accordingly, primitive accumulation is conceived as 'those social processes or sets of strategies aimed at dismantling those institutions that protect society from the market' (2004: 13). In my view, one can only understand through this reading of Marx that, even if primitive accumulation were a problem of genealogy, the genealogy would manifest itself until a radical historical reversal would take place.

Marx's account of capital, a process of circulation of values which are congealed in different things at various points, refers to the ad infinitum movement in which money is recapitalized in search of more money (Harvey, 2010). 'What capital does is that it attempts to create life-worlds in its own image or to colonise existing ones, to put them to work for its priorities and drives ... since the beginning of its history ... until it has colonised all of life' (De Angelis 2004: 67). However, there arise some limits any one of which has to be transcended by capital. Marx (1993), in the Grundrisse, argues that the circulation and accumulation of capital cannot abide limits; whenever it encounters a limit, it turns them into barriers that then could be transcended or by-passed. At 
this point, Marx cites Hegel's Science of Logic as a footnote: 'something's own boundary posited by it as a negative which is at the same time essential, is not merely boundary as such but barrier ... and it does overcome it' (Hegel in Marx, 1993: 334). Marx adapts the argument for capital: 'capital is the endless and limitless drive to go beyond its limiting barrier ... Every limit appears as a barrier to overcome' (1993: 334 and 408). Capital is thusly conceptualised as a social force devoted to transcend every limit it encounters in order to expand itself continuously.

The "distinctive quality" of the Marxian limit which is tried to be overcome by capital through the strategies of ex-novo separation pertains to the tendency of workers' open-direct access to social wealth that is not mediated by the natural laws of capitalist mode of production. When capital's eternal desire to colonise and accumulate is constrained or threatened by the workers, capital encounters with an alarming situation. In cognitive capitalism, the becoming-centrality of the common provides a political opportunity for workers to invert the essential separation and claim their autonomy in relation to capital. In this context, capital strives to separate people ex-novo from the growing common forms of wealth by mobilising aggressive commodification strategies such as intellectual property rights.

\section{A Structural Contradiction: The Enclosure of the Common through Intellectual Property Rights}

From the standpoint of classical economics and property law, the system of private property (be it real estate or intellectual property) rights is based on two levels of provisions. The first level concerns the rules, norms, conventions, laws, etc. (these are the forms of obligations in differing intensity) that establish the usus (the delimitation of uses), fructus (the exclusive right to enjoy), and abusus (the alienability; the ability to exchange at mutually agreeable terms) of goods, where good is understood to be anything that is recognised as an object of economic, symbolic or social value (Alchian, 2019). The second level concerns the institutional arrangements, that is, the 
conditions for the enforcement of those laws, rules, and so forth. These two levels are interrelated inasmuch as if the forms of obligation are ignored, they fall into disuse and the character of enforcement is rendered obsolete.

In industrial capitalism, on the whole, the jurisdictional and institutional arrangements which inform the nature and execution of private property rights in general, and intellectual property rights in particular were not a subject of major debate for two reasons. First, in industrial capitalism 'the production of wealth and value is [largely] based on material production and manual labour' (Morini and Fumagalli, 2010: 235) and, accordingly, the volume of "intellectual" products such as knowledge(s), designs, ideas, codes, images along with the artefacts which are innately not separable (divisible), rival, and excludible was quite limited. Second, the formation of monopoly with regard to the trade of intellectual products was firmly established and regulated by the system of i) patents, ii) trademarks/branding, and iii) copyrights. These mechanisms secured the unity of usus, abusus and fructus of intellectual goods and enabled the transformation of them into scarce goods on the market, thusly providing the tenant of IPR legal right to have monopoly. The evolving technical means of reproduction surely challenged the IPR enforcement by overstepping the legal apparatuses, which was followed by a new writing of the $\operatorname{law}(\mathrm{s})$.

In cognitive capitalism, the issue of IPR, has become a central topic. The legal proceedings and the increasing court cases over the conflicts of IPR are indeed everywhere (Reuters, 2014). It is not a coincidence that in 1996, a journal was launched which was dedicated to this subject (i.e. Journal of Intellectual Property Rights). Here, we may underline two main interrelated reasons. Firstly, as discussed in the previous sections, the value and wealth have increasingly come to rest on immaterial production (and its intellectual products) which is increasingly conducted within and through the common. This corresponds to the tendency of workers' re-appropriation of intellectual powers of production, reversal of workers' separation from the means of production, 
and hence their increasing autonomy in terms of production relations; a tendency which creates a distressing situation from the perspective of capital.

This "distressing" situation, secondly, was raised to an "alarming" situation with the tendential breakdown of the strong links between usus, fructus, and abusus, which was engendered by the force of digital revolution. The new information and communication technologies transformed the results of immaterial production (i.e. intellectual products) into a sequence of binary digits via, for instance, software compression and encryption. In the digital world, the reproduction which is based on meta-data is virtually identical with the original, whereas in the analogical world the latter is always distinguishable, for it is necessary to utilise a physical medium (e.g. tape recorder) for the process of its reproduction. Since the digital data could be coded in the digital media, reproduced, and delivered virtually at zero marginal cost, the inversion of scarcity of creative, social, knowledge commons in relation to intellectual goods has come to the forefront. The rise of 'digital multitudes', the elimination of the limits to reproduction, the inversion of scarcity of commons, the developments in the capacity for the repository of intellectual goods have culminated in the 'limited user rights, conditional fructus, and non-alienability' (Boutang, 2011: 106) of intellectual goods.

As a response to this "alarming" situation, we have witnessed an aggressive plan directed towards enclosing the commonality of immaterial production through IPR. To mention a few, some strict measures [i.e. laws and treaties] were set out, via the World Trade Organisation (WTA), in the Agreement on Trade-Related Aspects of Intellectual Property Rights (TRIPS Agreement), as finalised at the Marrakesh Agreement in 1994. The measures were then strengthened in Doha Development Rounds. In 1998, Digital Millennium Copyright Act (DMCA) passed in the United States, followed by the European Union Copyright Directive in 2001. The final version of the Directive on Copyright in the Digital Single Market by EU was approved on 26 March 2019. 
According to the World Intellectual Property Organisation (WIPO), there are currently twentysix international intellectual laws, treaties and conventions, binding 191 member-states legally .

In cognitive capitalism, nevertheless, the process of enclosure through enforcement of IPR manifests a paradox or, using Marxian terminology, a structural contradiction in two ways. First, capital's attempts to enclose the commons through IPR in order to (re)establish hegemony over intellectual powers of production actually inhibits the development of productive forces, and thereby capital prepares its own social crisis in terms of established relations of production. Second, the enclosure through IPR curtails the business opportunities in terms of innovation, profit-making, and growth. In what follows, I will discuss these two critical points.

Marx's (1977) theory of societal transformation has three key elements which are articulated in the Preface to A Contribution to the Critique of Political Economy vii. Human beings produce their livelihoods by working together. The way in which this production is organised becomes objectified into certain relations of production which are administered by a ruling class that exploits the people at the bottom -as in the cases of feudalist and capitalist relations of production. The ruling class then institutes a political and ideological superstructure, diffusing and imposing certain ways of thinking and living, to maintain the exploitation process. However, Marx notes, there is a tendency in human history for human beings to create new ways of producing which confront both the existing relations of production and superstructure, that is, a tendency which might result in a crisis and class struggle for the transformation of the mode of production. Harman (2006, para. 25) recapitulates Marx's argument well: 'the rise in the forces of production begin to change relations of production at the micro level, which then challenges the wider relations of production, the political superstructures and the ideologies of the older order [and in turn class relations], which lead to potentially revolutionary upheavals'. 
Marx's general theory of social transformation is articulated in his and Engels's (2004) reading of the transition from feudal mode of production to the capitalist mode of production. Marx and Engels discuss how feudal relations could not contain already developed productive forces in itself and thereby was inevitably superseded by a new relation of property, to wit capitalist relations of property. In particular, they state that:

We see then: the means of production and of exchange, on whose foundations the bourgeoisie built itself up, were generated in feudal society. At a certain stage in the development of these means of production and exchange, the conditions under which feudal society produced and exchanged, the feudal organisation of agriculture and manufacturing industry, in one word, the feudal relations of property became no longer compatible with the already developed productive forces; they became so many fetters. They had to be burst asunder; they were burst asunder. (Marx and Engels, 2004: 9-10, emphasis added)

The significant question is, then, whether the social productive forces, or rather the human, social, and subjective powers are in a process of being fostered, expanded, and developed to their fullest in a particular mode of production. To put it differently, the question is really concerned with whether the enclosure of the common via IPR contradicts with the expansion of human, social, and subjective forces in cognitive capitalism.

We have argued in the first section of this article that immaterial labour performs creatively and productively only within and through the common. In a plain expression, the production process begins with an access to the common resources and, at the end of the process, provides muchenriched common which, in turn, must be open and directly accessible to be the foundation for a new cycle of production. An undisturbed accumulation of the common, in my point of view, corresponds precisely to the development of social productive forces. By immaterial production 
or by accumulation of the common wealth, it is meant not solely some quantitative expansion of our forces (e.g. more information, more knowledge) but also, and above all, that 'our powers and senses increase: our powers to think, to feel, to see, to relate to one another, to love'; that is, our relational and productive qualities and capabilities (Hardt and Negri, 2009: 283). At a higherlevel of abstraction, immaterial production comes to convey not the production of objects for subjects but the production of forms of life, subjectivity: the bios. Hardt and Negri reflect on immaterial production through the term of biopolitical production and put that: 'the immaterial production ... [is] the the production of subjectivity through the common and the production of common through subjectivity ... [a blockage in the common] should be understood, then, as a blockage in the production of subjectivity' (2009: 299-300).

From this perspective, the enclosure of the common should be considered a structural fetter on the development and growth of human beings. In particular, intellectual property rights act as forms of structural restraints for the expansion and development of productive forces. They block the qualities and capabilities, that is, the very human potentiality of wage-workers. They precisely interrupt the Foucauldian circuit in which l'homme produit l'homme (man produces man). In this regard, it is fair to state that by imposing IPR, capital prepares its own social crisis in terms of established capitalist relations of production.

Furthermore, the enclosure through IPR hinders the opportunities for innovation, profit-making, and growth. From the perspective of neoclassical economics, Boldrin and Levine $(2002,2010)$ challenge the 'common argument [that] the presence of strong intellectual property rights spurs innovation leading to higher economic growth and increasing benefits for all' (2002: 209). By drawing on quantitative models, they analyse the difference between property rights applied to material and immaterial goods and show that IPR constitute a monopoly, 'intellectual monopoly', ultimately hindering free market, competition, growth, and wealth. Again, from the perspective of neoclassical economics, Lerner examines the impact of IPR policy shifts in 60 nations over the 
past 150 years and finds a 'lack of a positive impact of strengthening of patent protection on innovation' (2009: 347), which is key for profit making and economic growth. Martin (1998) inquiries into the relationship between IPR and innovation from a different perspective. By using real-life cases, he demonstrates how big companies purchase someone else's idea to inhibit other companies from transforming this idea to an innovative product and selling it on the market as a competitor of their product. Along the same lines, Baker, Jayadev and Stiglitz's comprehensive policy- paper argue that 'the current global regime of intellectual property rights is inadequate in serving the purpose of development and welfare ... both in developed and developing countries' (2017: 7). They state that 'if the knowledge economy and the economy of ideas is to be a key part of the global economy and if static societies are to be transformed into 'learning societies' that are key for growth and development, there is a desperate need to rethink the current regime [of IPR]' (2017: 7). The famous Manchester Manifesto, signed by fifty international scholars from various disciplines, underlines 'the significant drawbacks' of IPR in 'its effects on economic efficiency' (2009:2), especially in terms of 'reducing competition and allowing large companies to dominate markets' (2009: 4).

My own perspective is informed by Boutang $(2011,2013)$ who underscores 'the absolute and internal need for this kind of capitalism, cognitive capitalism' to disclose, that is to say 'to create the spaces [the commons in general] of liberty and new digital commons as a fundamental and inescapable condition for extracting value' (Boutang, 2013: 90). He grounds his argument in the idea of 'human pollination'. We have noted that the originality of cognitive capitalism 'consists in capturing, within a generalised social activity, the innovative elements which produce value' (Negri, 2008: 64). In other words, economic value depends increasingly on the pollination of "human bees", interacting and participating within and through the common. The remarkable difference between industrial capitalism and cognitive capitalism lies in the fact that 'the former needed to destroy the ancient commons in order to transform the independent worker into proletariat whereas the later requires disclosure and constitution of a new kind of commons 
(Boutang, 2013: 90-1). From the perspective of capital, therefore, the implementation of IPR blocks the common's richness, and this is another way of saying farewell to the profit opportunities offered by the knowledge society.

\section{Conclusion}

Is the implementation of intellectual property rights a socio-economic need -as it is largely advocated in the literature? Focusing on the contemporary state of socio-economic affairs, informed by cognitive and digital turn, this article attempted to provide an autonomist Marxist critical update on the concept of intellectual property rights, and argued that the enclosure of commons through the strict regime of intellectual property rights acts as a barrier before economic health. By economic health, we should not understand the present-day performance of an economy identified by a set of quantitative indicators such as gross domestic product, country deficit, inflation-rate, currency rate, and so forth. According to Schumpeter, 'capitalist performance is not even relevant for prognosis' of capitalism's future' (2010: 115). Economic health, rather, concerns the question of whether there exists a structural contradiction acting as a fetter on the development of productive forces as well as economic growth. In this regard, we theoretically argued that the regime of intellectual property rights, directed towards separating workers from the ownership of means of production, does not only curtail the actualisation of workers' potentiality and block the development of productive forces but it also curtails the socioeconomic opportunities for innovation, profit-making, and growth.

\section{Endnotes}

\footnotetext{
${ }^{\mathrm{i}}$ I would like to thank three referees as well as the editors for their critical comments that have motivated me to read and learn more and develop and clarify the ideas presented here. I also would like to thank Prof. Mollie Painter who always encourages me to write speculative pieces as well as my colleague Natalie Toms (Miss Nando) who proofread the text.
} 
ii For autonomist Marxist theorist, the distinction between bourgeois (capitalists) and proletariat (workers) is -what Roth (2019) calls- a 'right distinction', that is, 'mutually exclusive and jointly exhaustive'.

iii a) MATISSE, Modélisations Appliquées, Trajectoires Institutionnelles, Stratégies SocioÉconomiques, is a research centre at University of Paris I Panthéon-Sorbonne where the research programme of cognitive capitalism was first introduced and developed. One of the earliest theory paper on cognitive capitalism was written in 2001 by the members and external associates of the centre: Corsani P, Dieuaide B, Boutang YM, Paulré A, Monnier JM, Lazzarato M, Vercellone C (see the references) b) Autonomist Marxism (operaismo and post-operaismo) is not a unified research stream but collective effort whose theoretical and practical engagements have always shown a great degree of variation (see Wright, 2002). This is also case in terms of the thesis of cognitive capitalism and immaterial labour, see the critique of cognitive capitalism by Lazzarato (2014, 2015) and of immaterial labour by Dyer-Witheford (2001).

iv The various pillars of the theory of cognitive capitalism in general and the concept of immaterial labour in particular have been challenged by many critical scholars, including Callinicos (2001), Dyer-Witheford (2001), Thompson (2005), Camfield (2007), Gill and Pratt (2008), Lanoix (2012). In this paper, it is not possible to delve into these criticisms and the ensuing discussions. However, it is important to note that the point of reference of all these challenges lies largely in Hardt and Negri's trilogy (Empire, Multitude, Commonwealth), which were written by the simplification of theory and in a provocative tone to mobilise human bodies towards partisan action. The publications of Invisible Committee via MIT-Semiotext(e) keep this form of expression alive. One who is interested in how these challenges are addressed at a more robust theoretical level might want to look at Negri (1992), Vercellone (2007), Casarino and Negri (2008), Negri (2008), Fumagalli and Mezzadra (2010), Hardt and Negri (2009), Lucarelli and Vercellone (2013), Vercellone (2013). In addition, a sound analysis of these discussions can be found in the special issue of Ephemera on Immaterial and Affective Labour, Dowling, Nunes and Trott (2007).

v One of the important figures of autonomist Marxist thinking, Lazzarato $(2014,2015)$, does not agree with this postulate. He finds it too optimistic and argues, through Deleuze and Guattari, that capital achieved to produce "self-negating" and "automatically responsive" worker-subjectivity in tune with the priorities of capital (also see his arguments in Karakilic, 2017).

${ }^{v i}$ This type of linear reading of the development of capitalism is evident in Lenin's (1899) The Development of Capitalism in Russia in which he considered the expropriation of peasants as a "positive" and inevitable process in the creation of capitalist market in Russia.

vi The transition "problem" is necessarily of enormous interest to Marxists. At a very abstract level, one might categorise different perspectives into two groups: i) Sweezy-Wallterstein perspective, explaining transition via external forces (e.g. the growth of trade and market); ii) Brenner-Harman perspective, inspired by Dobb, explaining transition via internal forces. The second perspective is not unified. Brenner (along with Wood, Comninel, Teschke), the stream of Political Marxism, holds that a set of external conditions (e.g. the Black Death) unintentionally produces crisis in the existing relations of production (Brenner calls, 'social-property relations'/ 'the rules for reproduction') which culminates in class struggle towards a radical transition. They mark Marx's own writings specifically on this topic as 'production determinism' (Brenner, 2006). Harman and Heller, informing my perspective, stay dedicated to Marx and consider advances in productive forces anterior. Simply put, the advances in the forces of production throw up new antagonism in class relations, which ultimately culminates in the transcendence, by way of revolutionary overthrow, of old mode of production and its relations. For Harman and Heller (and this author), accordingly, the seeds of new mode of production are to be found precisely in the dynamics of old one. The Marxist literature on transition problem is vast. A good starting point might be Hilton (ed.) 1978, Aston and Philpin (eds.) 1995, Harman and Brenner discussion 2006. 


\section{References}

Alchian AA (2019) Property rights. The Library of Economics and Liberty. Available at: http://www.econlib.org/library/Enc/PropertyRights.html

Archibugi D and Filippetti (2018) The retreat of public research and its adverse consequences on innovation. Technological Forecasting and Social Change, 127, 97-111.

Aston TH and Philpin CHE (eds) (1995) Brenner Debate. Cambridge: Cambridge University Press.

Baker D, Jayadev A and Stiglitz JE (2017) Innovation, Intellectual Property, and Development. Available at: http://ip-unit.org/wp-content/uploads/2017/07/IP-for-21st-Century-EN.pdf

Boldrin M and Levine D (2002) The case against intellectual property. American Economic Review, 92(2), 209-212.

Boldrin M and Levine D (2010) Against Intellectual Monopoly. Cambridge: Cambridge University Press.

Bollen L, Vergauwen P and Schnieders S (2005) Linking intellectual capital and intellectual property to company performance. Management Decision, 43(9), 1161-1185.

Bonefeld W (2001) The permanence of primitive accumulation: Commodity fetishism and social constitution. The Commoner, September (2), 1-3.

Bonefeld W (2002) History and social constitution: Primitive accumulation is not primitive. The Commoner, Section on Debate on Primitive Accumulation, 1-7. Available at: http://www.commoner.org.uk/02bonefeld.pdf (accessed September 2018).

Boutang YM (2011) Cognitive Capitalism. Cambridge: Polity

Boutang YM (2013) Is the cup of struggle on the battle of intellectual property rights half full or half void? A question of method and some concrete consequences. Knowledge Cultures, 1(4), 8498.

Callinicos A (2001) Toni Negri in perspective. International Socialism, 2(92). Available at: https://www.marxists.org/history/etol/writers/callinicos/2001/xx/toninegri.htm

Camfield D (2007) The multitude and the kangaroo: A critique of Hardt and Negri's theory of immaterial labour. Historical Materialism, 15(2), 21-52.

Casarino C and Negri A (2008) In Praise of the Common: A Conversation on Philosophy and Politics. Minneapolis: University of Minnesota Press.

Castellano L, Cavallina A, Cortiana G et al. (1996) Do you remember revolution? In: Virno P and Hardt M (eds) Radical Thought in Italy: A Potential Politics. Minneapolis: University of Minneapolis Press, pp. 225-241.

Cerqueti R, Quaranta AG and Ventura M (2016) Innovation, imitation and policy inaction. Technological Forecasting and Social Change, 111, 22-30.

Cleaver H (2000) Reading Capital Politically. 2nd ed. Edinburgh: AK Press. 
Corsani A, Dieuaide P, Boutang YM et al. (2001) Le capitalisme cognitif comme sortie de la crise du capitalisme industriel: un programme de recherche, Actes du Forum de la Régulation. Available at:http://webcom.upmfgrenoble.fr/regulation/Forum/Forum_2001/Forumpdf/01_CORSANI_et _alii.pdf (Accessed January 2019).

De Angelis M (1999) Marx's theory of primitive accumulation: A suggested reinterpretation. Available at: http://homepages.uel.ac.uk/M.DeAngelis/PRIMACCA.htm (accessed September 2018).

De Angelis M (2001) Marx and primitive accumulation: The continuous character of capital's 'enclosures'. The Commoner, September (2), 1-22.

De Angelis M (2004) Separating the doing and the deed: capital and the continuous character of enclosures. Historical Materialism. 12(2), 57-87.

Denicolò V and Franzoni LA (2003) The contract theory of patents. International Review of Law and Economics. 23(4), 365-380.

Dieuaide P, Paulré B and Vercellone C (2003) Le capitalisme cognitif: Un nouveau système historique d'accumulation. Journées d étude MATISSE, Université de Paris 1. Available at: https://core.ac.uk/download/pdf/52833194.pdf

Dobb M (1963) Studies in the Development of Capitalism. London: Routledge.

Dowling E, Nunes R and Trott (2007) Immaterial and affective labour: Explored. Ephemera, 7(1), 1-8.

Dyer-Witheford N (2001) Empire, immaterial labor, the new combinations, and the global worker. Rethinking Marxism, 13:(3-4), 70-80.

Fuchs C (2010) Labor in informational capitalism and on the internet. The Information Society, 26(3), 179-196.

Fumagalli A (2011) Twenty theses on contemporary capitalism (cognitive biocapitalism). Angelaki, 16(3), 7-17.

Fumagalli A and Mezzadra S (eds) (2010) Crisis in the Global Economy: Financial Markets, Social Struggles, and New Political Scenarios. Los Angeles: Semiotext(e).

Gill R and Pratt A (2008) In the social factory? Immaterial labour, precariousness and cultural work. Theory, Culture \& Society, 25(7-8), 1-30.

Gould D and Gruben W (1996) The role of intellectual property rights in economic growth. Journal of Development Economics, 48(2), 323-350.

Gorz A (1997) Miseres du Present, Richesses du Possible. Paris: Galilee.

Hardt M (2011) Reclaim the common in communism. The Guardian, 3 February. Available at: https://www.theguardian.com/commentisfree/2011/feb/03/communismcapitalismsocialism-property (Accessed 7 February 2019).

Hardt M and Negri A (2000) Empire. Cambridge, MA: Harvard University Press. 
Hardt M and Negri A (2004) Multitude: War and Democracy in the Age of Empire. New York: Penguin.

Hardt M and Negri A (2009) Commonwealth. Cambridge, MA: Harvard University Press.

Harman C and Brenner R (2006) The origins of capitalism. International Socialism, 111. Available at: https://www.marxists.org/archive/harman/2006/xx/wbrenner.htm

Harvey D (2010) A Companion to Marx's Capital. London: Verso.

Hilton RH et al. (eds) (1978) The Transition from Feudalism to Capitalism. London: Verso.

Horlbulyk TM (1993) Intellectual property rights and technological innovation in agriculture. Technological Forecasting and Social Change, 43(3-4), 259-270.

Hu M-C and Hung S-C (2014) Taiwan's pharmaceuticals: A failure of the sectoral system of innovation? Technological Forecasting and Social Change, 88, 162-176.

Karakilic E (2017) Five theses on debt economy. Capital \& Class, 41(3), 561-567.

Lanoix M (2012) Labor as embodied practice: The lessons of care work. Hypatia, 28(1), 85-100.

Lazzarato M (1996) Immaterial labour. In: Virno P and Hardt M (eds), Radical Thought in Italy: A Potential Politics, Minneapolis: University of Minneapolis Press, pp. 133-151.

Lazzarato M (2014) Sign and Machines: Capitalism and the Production of Subjectivity. Los Angeles, CA: Semiotext(e).

Lazzarato M (2015) Governing by Debt. Los Angeles, CA: Semiotext(e).

Lenin V (1899) The Development of Capitalism in Russia.

Available at: https://www.marxists.org/archive/lenin/works/1899/devel/

Lerner J (2009) The empirical impact of intellectual property rights on innovation: Puzzles and clues. The American Economic Review, 99(2), 343-348.

Levy M and Jouyet J (2006) L'économie de l'immatériel : la croissance de demain. Ministre de

l'Économie, des Finances et de l'Industrie, Paris. Available at: http://www.ladocumentationfrancaise.fr/rapports-publics/064000880/index.shtml (accessed September 2018).

Lucarelli S and Vercellone C (2013) The thesis of cognitive capitalism. New research perspectives. An introduction. Knowledge Cultures, 1(4), 15-28.

Manchester Manifesto Group (2009) Who Owns Science? The Manchester Manifesto. Available at: http://www.isei.manchester.ac.uk/TheManchesterManifesto.pdf

Martin B (1998) Information Liberation: Challenging the Corruptions of Information Power. London: Freedom Press.

Marx K (1971) Theories of Surplus Value, v. 3. Moscow: Progress Publishers.

Marx K (1977) A Contribution to the Critique of Political Economy. Moscow: Progress Publishers. 
Marx K (1990) Capital: A Critique of Political Economy, v. 1. London: Penguin.

Marx K (1992) Capital: A Critique of Political Economy, v. 3. London: Penguin.

Marx K (1993) Grundrisse: Foundations of the Critique of Political Economy. London: Penguin Books.

Marx K and Engels F (2004) The Communist Manifesto. London: Penguin.

Morini C and Fumagalli A (2010) Life put to work: Towards a life theory of value. Ephemera, $10(3 / 4), 234-252$.

Negri A (1992) Marx Beyond Marx: Lessons on the Grundrisse. London: Pluto Press.

Negri A (2008) Reflections on Empire. Cambridge: Polity.

Park WG and Ginarte JC (2007) Intellectual property rights and economic growth. Contemporary Economic Policy, 15(3), 51-61.

Paulré B (2000) De la 'new economy' au capitalisme cognitif. Multitudes, 2(2), 25-42.

Pérez JHA, Kunc MA, Durst S et al. (2018) Impact of competition from unregistered firms on R\&D investment by industrial sectors in emerging economies. Technological Forecasting and Social Change, 133, 179-189.

Roth S (2019) Digital transformation of social theory. A research update. Technological Forecasting and Social Change, 146, 88-93.

Schumpeter JA (2010) Capitalism, Socialism and Democracy. London: Routledge.

Stiglitz JE (2014) Intellectual property rights, the pool of knowledge, and innovation. The National Bureau of Economic Research. Working paper no. 20014. Available at: The retreat of public research and its adverse consequences on innovation

Suh D and Oh D (2015) The role of software intellectual property rights in strengthening industry performance: Evidence from South Korea. Technological Forecasting and Social Change, 92, 140154.

Sweet CM, Maggio E and Sacha D (2015) Do stronger intellectual property rights increase innovation? World Development, 66(C), 665-677.

Sweezy P (1986) Feudalism to capitalism revisited. Science and Society, 50(1), 81-95.

Taylor FW (1911) The Principles of Scientific Management. New York: Harper \& Brothers.

Thompson P (2005) Foundation and empire: A critique of Hardt and Negri. Capital \& Class, 29(2), 73-98.

Thrift N (2011) Foreword to cognitive capitalism. In Boutang YM. Cognitive Capitalism. Cambridge: Polity, pp. vi-xi.

Toscano A (2009) Chronicles of insurrection: Tronti, Negri and the subject of antagonism. Cosmos and History: The Journal of Natural and Social Philosophy, 5(1), 76-91. 
Tronti M (1979) Lenin in England. In: Rosser B (ed.), Working Class Autonomy and the Crisis: Italian Marxist Texts of the Theory and Practice of a Class Movement, 1964-79. London: Red Notes.

Vercellone C (2005) The hypothesis of cognitive capitalism. In: Historical Materialism Annual Conference, Available at:

https://halshs.archivesouvertes.fr/file/index/docid/273641/filename/The_hypothesis_of_Cog nitive_Capitalismhall.pdf

Vercellone C (2007) From formal subsumption to general intellect: Elements for a Marxist reading of the thesis of cognitive capitalism. Historical Materialism, 15(1), 13- 36.

Vercellone C (2013) From the mass-worker to cognitive labour: Historical and theoretical considerations. In: Linder M and Roth KH (eds), Beyond Marx: Theorising the Global Labour Relations of the Twenty-First Century, Leiden: Koninklijke Brill NV, pp. 417-445.

Vercellone (2017) The Common as a mode of production. Towards a critique of the political economy of common goods. In: $A$ Conference by The Research Centre on Labour and Global Production at Queen Mary University of London. Available at: http://generation-online.org/c/fc rent14.htm (Accessed 7 February 2019).

Virno P (1996) Notes on the general intellect. In: Makdisi S, Casarino C, and Karl R (eds), Marxism Beyond Marxism, London: Routledge, pp. 265-273.

Virno P (2007) General intellect. Historical Materialism, 15(3), 3-8.

Willoughby KW (2013) What impact does intellectual property have on the business performance of technology firms? International Journal of Intellectual Property Management, 6(4), 316-338.

Wright S (2002) Storming Heaven: Class Composition and Struggle in Italian Autonomist Marxism. London: Pluto Press. 